\title{
COMPARITIVE BENEFITS OF BEEKEEPING ENTERPRISE IN CHITWAN, NEPAL
}

\author{
Suroj Pokhrel (PhD) ${ }^{1}$
}

\begin{abstract}
Based on the survey cunducted in 2004, beekeepers in Chitwan had small and fragmented land holdings with lower rate of return from subsistence crop farming. They are keeping Apis mellifera L.in Langstroth hive in Terai and A. cerana Fab. in improved, traditional-log and wall hives in hills, for honey production purpose. The honey productivity in Terai was 3.54 folds higher (28.7 vs 8.1 $\mathrm{kg} / \mathrm{yr} / \mathrm{hive}$ ) than in hills with highest average annual income in Bharatpur area followed by East and West Chitwan. Moreover, the income of the beekeepers in Chitwan from honey production was 3.62 folds higher than crop farming (NRs $83,996.88$ vs NRs 23,214.22 /house hold/year). It clearly showed that beekeeping with $A$. mellifera in the Terai is potential enterprise for higher income compared to crop production.
\end{abstract}

Key words: annual income, apiculture, crop production, honey productivity, land holding.

\section{INTRODUCTION}

Bee Keeping Section (2004) reported 1,27,501 honeybee colonies including 1,01,684 traditional (log and wall hives) and 25,200 improved ( $A$. cerana 17,744 and $A$. mellifera $7,456)$ hives kept in Nepal. The annual honey production is estimated $529.3 \mathrm{mt}$ and it is one of the exporting, high value cash earning commodities in Nepal. Honey export in the year 2003 was equivalent to Rs 4,41,985 and was 4439.2 folds higher than that of 2002 (Bee Keeping Section, 2003). However, the role of bees as crop pollinators has been largely ignored and a vast potential, in using bees to augment national income through increased crop production has been forgotten. Honey production and crop pollination have to be exploited for the agriculture development and poverty reduction in Nepal. The Asiatic honeybee, A. cerana is adopting by the hill caste community and A. mellifera in Terai of Chitwan (DADO, 2004; DADO, 2005). The total estimated honeybee colony in Chitwan is 7500 (A. mellifera 5500 and A. cerana 2000) (Neupane, 2002). Chitwan seems to be the potential district enriched with apicultural raw materials, labor, and market. However, increasing use of agrochemicals specially the pesticide use on crop protection is a emerzing threat. Nectar and pollen as raw materials are available from both forest and cultivated areas. Development of road infrastructure provides easy bee migration in all the seasons (DADO, 2004; DADO, 2005). More over, the services, institutional development, honey productivity and market development are not satisfactory. Beekeepers in Chitwan are in hurdele from different managerial, technical, ecological, behavioral and socio-economical problems and policy issues hindering the beekeeping industry. Beekeepers in Chitwan are mostly the medium class economic category, growing different crops and majority engazed in other occupation too. Thus, it was necessary to compare the income from beekeeping to crop production and study the market situation of honey in Chitwan. The objective of the study was to compare the income from beekeeping and crop production, to investigate the situation of honey market and make subsequent recommendation for the beekeepers in Chitwan.

1 Program Director, Crop Directorate, Department of Agriculture, Nepal, surojpokhrel@yahoo.com 


\section{MATERIALS AND METHODS}

\section{SURVEY SITE, TIME AND DURATION}

The survey was conducted in Chitwan district (Inner Terai and the peripheral Mahabharata hills) at central Nepal. The survey sites of $A$. cerana beekeepers were Chandibhanjyang, Shaktikhor, Korak and Siddhi VDCs. Similarly, survey of A. mellifera colonies was carried out in the Terai areas: East Chitwan (Pithuwa, Jutepani, Shaktikhor, Chainpur and Padampur VDCs and Ratnanagar Municipality), west Chitwan (Dibyanagar, Sukranagar and Parbatipur VDCs) and Bharatpur municipality during September-October 2004. Thse were the emerzing beekeeping pockets of Chitwan valley where number of beeflora are avilable and thousands of bee colonies in migrated during the honey flow season.

\section{BEEKEEPERS' INTERVIEW}

A questionnaire was developed, pre-tested, revised and the final version of which was duplicated and used for collecting necessary information from the beekeepers (65 households randomly selected out of the list prepared by Nepal Beekeepers Associatiopn) to see the income of beekeepers (from crop cultivation and honey production) and honey market situation in Chitwan. The information collected from the survey was verified with available literature.

\section{DATA PROCESSING}

Collected data were tabulated using MS-EXCEL software and necessary tables, graphs figures were prepared and means were calculated to draw the results regarding the size of land holdings, croped areas, food sufficiency, crop productivity, apiary sizes, labour use and house hold incomes from crop cultivation and honey production.

\section{RESULTS}

A survey of 65 beekeepers (36 in hills and 29 in Terai) was accomplished in 2004 to compare the gross income from crop cultivation and beekeeping and investigate the marketing situation of honey in hills and Terai of Chitwan.

\section{STATUS OF CROP PRODUCTION}

\section{Land holding}

The hill and Terai respondents had an average land holding of 0.70 ha (irrigated 0.12 ha) and 0.57 ha (irrigated 0.34 ha), respectively (Table 1). The beekeepers in West Chitwan had the highest land holding of 0.67 ha (irrigated $0.42 \mathrm{ha}$ ), followed by Bharatpur $0.57 \mathrm{ha}$ (irrigated $0.24 \mathrm{ha}$ ) and the least $0.53 \mathrm{ha}$ (irrigated $0.38 \mathrm{ha}$ ) in East Chitwan.

\section{Crop cultivated}

Crops cultivated in Terai were diversified than in hills. Most of the respondents $(82.8 \%)$ in Terai and nearly half of the respondents (44.4\%) in hills had lowlands. They grew rice, Oryza sativa $L$ in their lowland in rainy season. In the upland maize, Zea mays $L$. $(91.7 \%$, $\mathrm{N}=33$ in hills and $72.4 \%, \mathrm{~N}=21$ in Terai) and finger millet, Eleusine coracana Gaertn $(77.7 \%$, $\mathrm{N}=28$ in hills) were the major crops grew during the rainy season. While, mustard, Brassica campestris L. var dichotoma (Roxb.) Kitam. in Terai $(58.6 \%, N=17$ ) and buckwheat, Fagopyrum esculentum Moench $(36.1 \%, \mathrm{~N}=13)$ and mustard, $B$. campestris $(33.3 \%, \mathrm{~N}=12)$ in 
hills were the major crops grew during winter. The respondents also grew sesame, Sesamum orientale L. (17.2\%, $N=5)$; buckwheat, $F$. esculentum $(17.2 \%, N=5)$ and nizer, Guizotia abyssinica (L.) Cass. to some extent in Terai. Other minor crops included vegetable; wheat, Triticum aestivum L.; lentil, Lens esculenta Moench; blackgram, Phaseolus mungo L.; potato, Solanum tuberosum L.; cowpea, Vigna unguiculata (L.) Walp; sunflowers, Helianthus annuus L.; litchi, Litchi chinensis Sonner; mandarin orange, Citrus reticulata Balanco and greengram, Phaseolus aureus Roech (Table 2).

Table 1. Land holding of the beekeepers in Chitwan, 2004

\begin{tabular}{llll}
\hline \multirow{2}{*}{ Geographical area } & \multicolumn{2}{l}{ Land holding (ha/household) } \\
\cline { 2 - 4 } & Upland & Lowland & Total \\
\hline Hills & 0.58 & 0.12 & 0.70 \\
West Chitwan & 0.25 & 0.42 & 0.67 \\
East Chitwan & 0.15 & 0.38 & 0.53 \\
Bharatpur & 0.33 & 0.24 & 0.57 \\
Terai average & 0.23 & 0.34 & 0.57 \\
District average & 0.41 & 0.33 & 0.74 \\
\hline
\end{tabular}

Table 2. Crops grown by the beekeepers in Chitwan, 2004

\begin{tabular}{|c|c|c|c|c|c|c|}
\hline \multirow{3}{*}{ Crops } & \multicolumn{6}{|c|}{ Respondent (\%) } \\
\hline & \multirow[t]{2}{*}{ Hills } & \multicolumn{4}{|c|}{ Terai } & \multirow{2}{*}{$\begin{array}{l}\text { Grand } \\
\text { Total }\end{array}$} \\
\hline & & West & East & Bht $^{*}$ & Total & \\
\hline Rice, Oryza sativa L. & $44.4(16)$ & $100(8)$ & $92.3(12)$ & $50.0(4)$ & $82.8(24)$ & $61.5(40)$ \\
\hline $\begin{array}{l}\text { Mustard, Brassica campestris L. var } \\
\text { dichotoma (Roxb.) Kitam. }\end{array}$ & $33.3(12)$ & $100(8)$ & $46.2(6)$ & $37.5(3)$ & $58.6(17)$ & $44.6(29)$ \\
\hline Maize, Zea mays L. & $91.7(33)$ & $75.0(6)$ & $92.3(12)$ & $37.5(3)$ & $72.4(21)$ & $83.0(54)$ \\
\hline Sesame, Sesamum orientale L. & & $37.5(3)$ & & $25.0(2)$ & $17.2(5)$ & $7.7(5)$ \\
\hline $\begin{array}{l}\text { Buckwheat, Fagopyrum esculentur } \\
\text { Moench }\end{array}$ & $36.1(13)$ & $62.5(5)$ & & - & $17.2(5)$ & $27.7(18)$ \\
\hline Vegetables & $11.1(4)$ & - & $7.7(1)$ & $37.5(3)$ & $13.8(4)$ & $12.3(8)$ \\
\hline Wheat, Triticum aestivum L. & $5.5(2)$ & - & - & $12.5(1)$ & $3.4(1)$ & $4.6(3)$ \\
\hline Lentil, Lens esculenta Moench. & & - & $7.7(1)$ & - & $3.4(1)$ & $1.5(1)$ \\
\hline Blackgram, Phaseolus mungo L. & $2.8(1)$ & - & - & - & - & $1.5(1)$ \\
\hline Potato, Solanum tuberosum L. & - & - & - & $25.0(2)$ & $6.8(2)$ & $3.1(2)$ \\
\hline $\begin{array}{l}\text { Finger millet, Eleusine coracana } \\
\text { Gaertn }\end{array}$ & $77.7(28)$ & - & - & - & - & $43.0(28)$ \\
\hline Cowpea, Vigna unguiculata (L.) Walp. & $5.5(2)$ & - & - & - & - & $3.1(2)$ \\
\hline Greengram, Phaseolus aureus Roech & $5.5(3)$ & - & - & - & - & $4.6(3)$ \\
\hline Nizer, Guizotia abyssinica (L.) Cass. & $5.5(2)$ & $25.0(2)$ & - & $37.5(3)$ & $17.2(5)$ & $10.8(7)$ \\
\hline Sunflowers, Helianthus annuus L. & - & - & $25.0(3)$ & - & $103(3)$ & $4.6(3)$ \\
\hline Litchi, Litchi chinensis Sonner & $2.8(1)$ & $37.5(3)$ & $16.7(2)$ & $37.5(3)$ & $27.6(8)$ & $13.8(9)$ \\
\hline $\begin{array}{l}\text { Mandarin orange, Citrus reticulata } \\
\text { Balanco }\end{array}$ & $19.4(7)$ & & - & - & - & $10.8(7)$ \\
\hline
\end{tabular}

Figures in parentheses show the respondent numbers.

* Bharatpur 
Income and food sufficiency

Per capita income from crop cultivation in hills (Rs 16122.20/household) was lower by 49.6\% than in Terai (Rs 32,018.00/household). It was comparatively higher in East Chitwan (NRs 34691.63) than in West Chitwan (NRs 31321.14) and Bharatpur (NRs 28370.50 /hh/year) in Terai (Table 3). Food from their farm production was only

Table 3. Beekeeper's land holdings, annual gross income from the crops and food sufficiency in Chitwan, 2004

\begin{tabular}{|c|c|c|c|c|c|}
\hline \multirow{2}{*}{$\begin{array}{c}\text { Geographical } \\
\text { area }\end{array}$} & \multirow{2}{*}{$\begin{array}{l}\text { Land hold. } \\
\text { (ha/hh) }\end{array}$} & \multirow{2}{*}{$\begin{array}{l}\text { Income from } \\
\text { crop (NRs) }\end{array}$} & \multirow{2}{*}{$\begin{array}{l}\text { Food suffi. } \\
\text { (months/yr) }\end{array}$} & \multicolumn{2}{|c|}{ Way to meet the deficiency } \\
\hline & & & & Source & Respondents (\%) \\
\hline \multirow[t]{2}{*}{ Hills } & \multirow[t]{2}{*}{0.70} & \multirow[t]{2}{*}{16122.20} & \multirow[t]{2}{*}{6.6} & Wage labor, & $41.7(15)$ \\
\hline & & & & Shop keeping & $5.6 \quad(2)$ \\
\hline West Chitwan & 0.67 & 31321.14 & 9.9 & Apiculture & $25.0(2)$ \\
\hline \multirow[t]{3}{*}{ East Chitwan } & \multirow[t]{3}{*}{0.53} & \multirow[t]{3}{*}{34691.63} & \multirow[t]{3}{*}{9.3} & Grocery & $37.5(3)$ \\
\hline & & & & Apiculture & $37.5(3)$ \\
\hline & & & & Metal-workshop & $37.5(3)$ \\
\hline \multirow[t]{2}{*}{ Bharatpur } & \multirow[t]{2}{*}{0.57} & \multirow[t]{2}{*}{28370.50} & \multirow[t]{2}{*}{5.1} & Civil service & $37.5(3)$ \\
\hline & & & & House renting & $12.5(1)$ \\
\hline Terai average & 0.57 & 32018.10 & 8.3 & - & - \\
\hline District mean & 0.41 & 23214.20 & 7.36 & - & - \\
\hline
\end{tabular}

Figures in parentheses show the respondent numbers

sufficient for 6.6 months in the hills and for 8.3 months in the Terai. It was highest in West Chitwan (9.9 months) followed by East Chitwan (9.3 months) and Bharatpur (5.1 months). The hill beekeepers fulfilled their additional requirements from wage labor while in the Terai, they derived their income sources from apiculture $(37.5 \%, \mathrm{~N}=3)$, grocery $(37.5 \%$, $\mathrm{N}=3)$, metal workshop $(37.5 \%, \mathrm{~N}=3)$, civil services, etc.

\section{STATUS OF BEEKEEPING}

\section{Purpose of beekeeping}

The purpose of beekeeping in Chitwan was mainly for income generation from honey production and selling. However, $27.8 \%$ hill and $86.0 \%$ Terai beekeepers also realized the role of honeybee on crop pollination and thereby crop diversification (Table 4). All beekeepers in Terai also produced wax from A. mellifera combs while it was insignificant in the hills.

Table 4. Main purpose of beekeeping in Chitwan, 2004

\begin{tabular}{llll}
\hline & Respondent $(\%)$ & & \\
Particular & Hills & Terai & Total \\
\hline Honey production & $100.0(36)$ & $100.0(29)$ & $100.0(65)$ \\
Wax production & $8.3(3)$ & $100.0(29)$ & $49.2(32)$ \\
Pollination awareness & $27.8(10)$ & $86.2(25)$ & $53.8(35)$ \\
\hline
\end{tabular}

Figures in parenthesis show the respondent number 
Among the respondent beekeepers, 27.8\% (N=10) in hill and $86.0 \%(\mathrm{~N}=25)$ in Terai were aware about the role of honeybees on pollination. The beekeepers in hills reported that the yield of mustard, B. campestris; citrus, C. reticulata; and buckwheat, F. esculentum rose by $10.0-25.0 \%$ from honeybee pollination. However, the Terai beekeepers realized the crop yield of cross-pollinated crops i.e. mustard, B. campestris; buckwheat, F. esculentum and litchi, L. chinensis rose up to $40.0 \%$ (Table 5).

Table 5. Crop productivity realized from honeybee pollination in Chitwan, 2004

\begin{tabular}{|c|c|c|c|c|c|c|}
\hline \multirow{3}{*}{ Production rose } & \multicolumn{5}{|c|}{ Respondent (\%) } & \multirow{3}{*}{$\begin{array}{l}\text { Grand } \\
\text { Total }\end{array}$} \\
\hline & \multirow[t]{2}{*}{ Hills } & \multicolumn{4}{|c|}{ Terai } & \\
\hline & & West & East & Bharatpur & Total & \\
\hline$<14 \%$ & $25.0(9)$ & - & - & $12.5(1)$ & $3.4(1)$ & $15.4(10)$ \\
\hline $14-25 \%$ & $2.8(1)$ & $75.0(6)$ & $53.8(7)$ & $50.0(4)$ & $58.6(17)$ & $27.7(18)$ \\
\hline $25-35 \%$ & - & - & 23.1 & $25.0(2)$ & $17.2(5)$ & $7.7(5)$ \\
\hline$>35 \%$ & - & - & $15.1(2)$ & - & $6.8(2)$ & $15.4(2)$ \\
\hline Mean & $14.1 \%$ & $20.6 \%$ & $30.4 \%$ & $22.1 \%$ & $25.4 \%$ & $19.1 \%$ \\
\hline
\end{tabular}

Figures in parentheses show the respondent numbers

\section{Species of honeybees}

Two domesticated honeybees: A. mellifera in Langstroth hive in Terai and A. cerana in 3 different hives (41.1\% in improved, $31.2 \%$ in traditional log and $27.6 \%$ in wall hives) mainly in hills, with an mean colony size of 4.4 per household $(\mathrm{N}=36)$ in hills and 50.0 per household $(\mathrm{N}=29)$ in Terai were adopted by the beekeepers in Chitwan (Table 6, Fig. 1). The mean colony number of $A$. mellifera was highest in Bharatpur $(87.5$ colonies/household) followed by East Chitwan (43.6 colonies/household) and West Chitwan (22.6 colonies/household), respectively.

Table 6. Honeybee species kept by the beekeepers in Chitwan, 2004

\begin{tabular}{llllllll}
\hline \multirow{2}{*}{ Particulars } & \multicolumn{2}{l}{ A. cerana } & \multicolumn{3}{l}{ A. millifera } & \multicolumn{2}{l}{ Total } \\
\cline { 2 - 8 } Colony number & Location & Colony & $\%$ & Colony & $\%$ & Colony & $\%$ \\
& Hills & 170 & 99.4 & 1 & 0.6 & 171 & 10.6 \\
& Terai & - & - & 1448 & 100 & 1448 & 89.4 \\
\multirow{5}{*}{ Hive types } & Total & 170 & 10.5 & 1449 & 89.5 & 1619 & 100 \\
& Hills: Improved & 70 & 41.2 & 1 & 100 & 71 & 4.4 \\
& Log & 53 & 31.2 & - & - & 53 & 3.3 \\
& Wall & 47 & 27.6 & - & - & 47 & 2.9 \\
Average & Terai: Improved & - & - & 1448 & 100 & 1448 & 89.4 \\
& Total & 170 & 100 & 1449 & 100 & 1619 & 100 \\
& Hills & $4.4(36)$ & - & $1(1)$ & - & $4.4(36)$ & - \\
& Terai & - & - & $50.0(29)$ & - & $50.0(29)$ & - \\
& East Chitwan & - & - & $43.6(13)$ & - & $43.6(13)$ & - \\
& Bharatpur & - & - & $87.5(8)$ & - & $87.5(8)$ & - \\
& West Chitwan & - & - & $22.6(8)$ & - & $22.6(8)$ & - \\
\hline
\end{tabular}

Figures in parentheses show the respondent numbers 


\section{Colony handling}

The range of the bee colonies per household ranges 4-250. The colony holding of A. cerana was found 4.4 /household, ranging from 4-12. The human resource involved to manage these colonies was 1.6/household and the range was 1-3. However, human resource engaged in keeping with A. mellifera in Terai ranged from 1-9 persons (Average 2.9/household). It was lower in West Chitwan (1.9 person/household) than in Bharatpur area (3 person/household) and in East Chitwan (3.5 person/household). Moreover, the per capita holding of A. mellifera colonies in Terai was significantly higher ( 50.0 colonies per

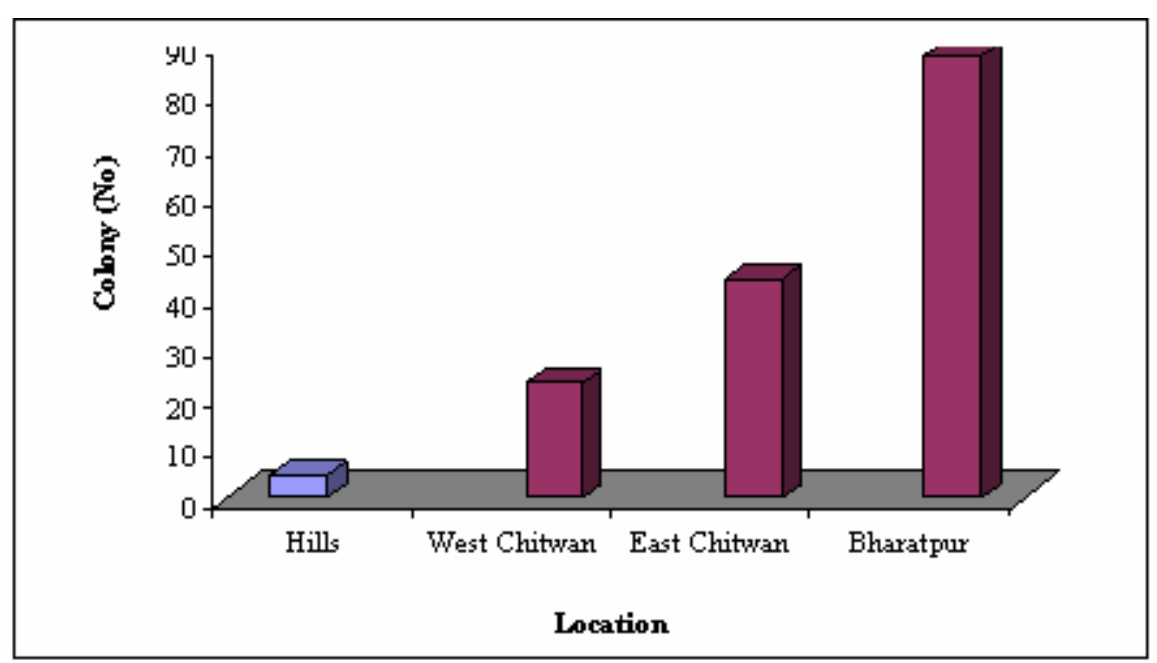
household), among the respondents. Where, it was extremely higher $(88.4$ colonies/household) in Bharatpur followed by East Chitwan (43.3 colony/household) and least in West Chitwan (23.3 colonies/household) (Table 7).

Figure 1. Mean number of colonies kept by beekeepers in Chitwan, 2004.

Table 7. Man power involved in beekeeping in Chitwan, 2004

\begin{tabular}{lllllll}
\hline Location & \multicolumn{3}{l}{ Honeybee colonies (No.) } & \multicolumn{3}{l}{ Labour involved (No./household) } \\
\cline { 2 - 7 } & $\begin{array}{l}\text { Range } \\
\text { /household }\end{array}$ & $\begin{array}{l}\text { Mean } \\
\text { /household }\end{array}$ & Total & \multicolumn{2}{l}{ Range } & \multicolumn{2}{l}{ Mean } & Total \\
& $4-12$ & 4.4 & $170(36)$ & $1-3$ & 1.6 & 57 \\
\hline Hills & $10-250$ & 50.0 & $1456(29)$ & $1-9$ & 2.9 & 85 \\
Terai & $10-65$ & 22,6 & $185(8)$ & $1-4$ & 1.9 & 15 \\
West Chitwan & $10-95$ & 436 & $563(13)$ & $1-7$ & 3.5 & 46 \\
East Chitwan & $10-250$ & 87.5 & $708(8)$ & $1-9$ & 3.0 & 24 \\
Bharatpur & $4-250$ & 25.0 & $1626(65)$ & $1-9$ & 2.2 & 142 \\
District total & & & & & & \\
\hline
\end{tabular}

Figures in parentheses show the respondent numbers.

\section{Honey production}

The productivity of $A$. mellifera was $254.3 \%$ higher $(28.7 \mathrm{~kg}$ vs $8.1 \mathrm{~kg} /$ colony/yr) than $A$. cerana (improved hive $8.6 \mathrm{~kg}$, log hive $7.7 \mathrm{~kg}$ and wall hive $7.4 \mathrm{~kg} / \mathrm{yr}$ ) (Table 8). The beekeepers harvested honey 2-7 (mean 3.2) times from A. cerana in autumn and spring in the hills and 3-7 times (mean 4.8) from A. mellifera in the Terai in winter and spring. East Chitwan farmers had the highest honey harvesting frequencies (5.3 times/year) with the highest productivity of $34.8 \mathrm{~kg}$ per colony per year followed by (Bharatpur 4.6 times with $25.1 \mathrm{~kg} /$ colony /year) and West Chitwan (4.2 times with $22.2 \mathrm{~kg} /$ colony /year) (Table $8)$. 
Table 8. Honey yield and harvesting frequency in Chitwan, 2004

\begin{tabular}{lccc}
\hline \multirow{2}{*}{$\begin{array}{c}\text { Geographical } \\
\text { location }\end{array}$} & $\begin{array}{c}\text { Yield } \\
(\mathrm{kg} / \mathrm{hive} / \mathrm{yr} .)\end{array}$ & \multicolumn{2}{c}{ Harvesting frequency (No./year) } \\
\cline { 3 - 4 } Hills & 8.1 & Range & Mean \\
Terai & 28.7 & $2-7$ & 3.2 \\
West Chitwan & 22.6 & $3-7$ & 4.8 \\
East Chitwan & 34.8 & $3-7$ & 4.6 \\
Bharatpur & 25.1 & $3-7$ & 5.3 \\
District mean & 26.5 & $3-6$ & 4.2 \\
\hline
\end{tabular}

\section{Honey price}

Honey price was found decreasing annually by $4.7 \%$ in Terai and by $3.9 \%$ in hills and was ranging from Rs $100-150 / \mathrm{kg}$ in 2004 . The average price of honey in the hills was $9.2 \%$ lower (Rs 104.7 vs $115.4 / \mathrm{kg}$ ) than in Terai, and was highest in Bharatpur (Rs 132.5 vs 108.9 and 109.9) than in East and West Chitwan (Table 9, Fig. 2).

Table 9. Market price of honey during 2000-2005 in Chitwan, 2004

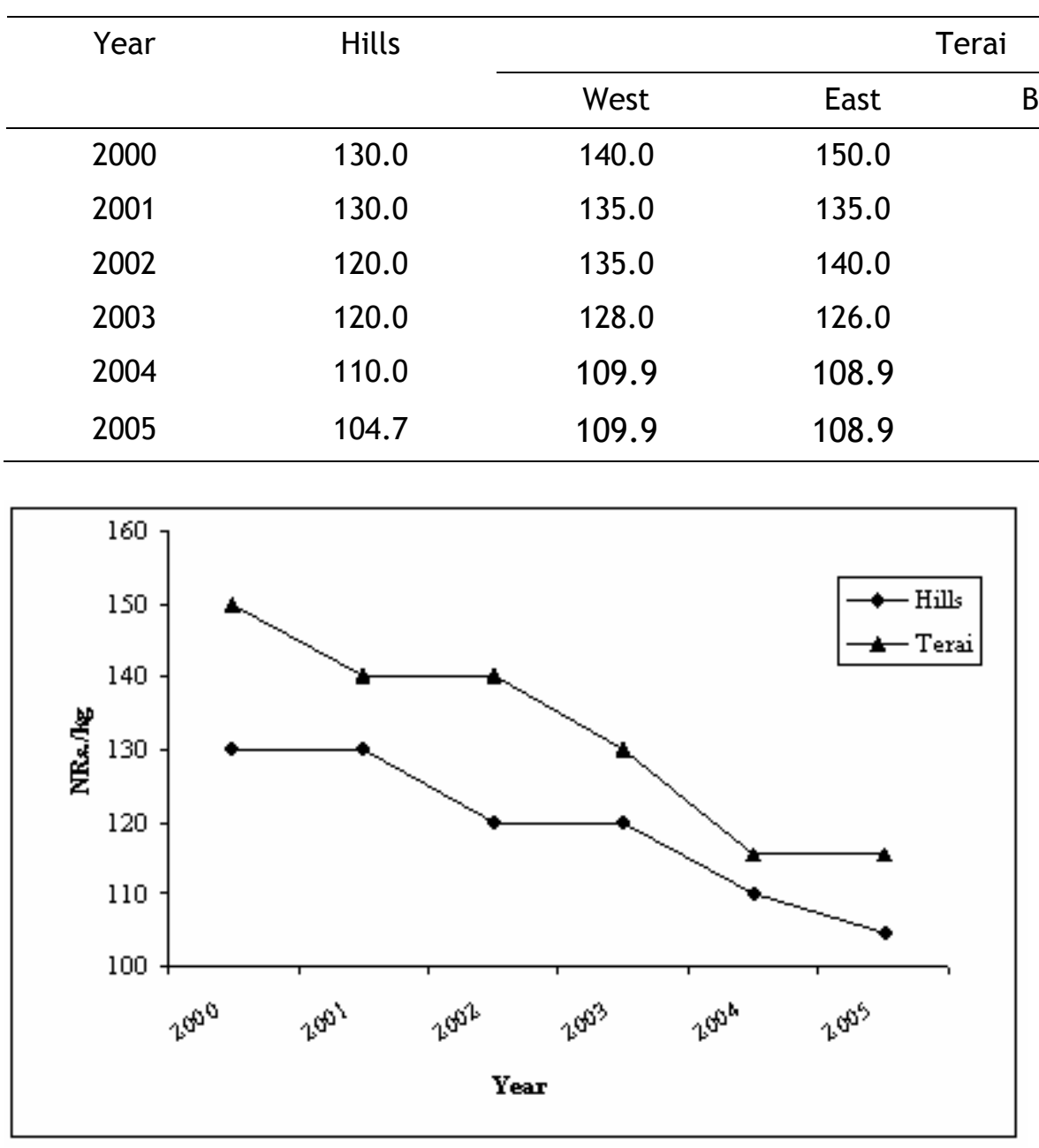

Figure 2. Honey price in Chitwan during 2000/20005 


\section{Honey marketing}

The hill beekeepers in Chitwan sold $A$. cerana honeycombs or hand squeezed honey in Terai. The small and medium beekeepers (72.4\%) in Terai supplied honey to the local market after wire/muslin cloth filtering. Some beekeepers also sold raw honey to the bigger farmers and or to Nepal Bee Keepers Association. Big farmers (27.6\%) were involved in home processing, packing and marketing of honey or sold it to bee association, and thus, had access to market with all sorts of consumers i.e. with in district, inter-district and even at the international level. Honey marketing channel in Chitwan is shown in Fig. 3.

A total of $17.2 \%$ of $A$. mellifera honey sold was seal packed and rest $(82.8 \%)$ was sold after wire/cloth filtered (Table 10).

Table 10. Types of honey marketed by beekeepers in Chitwan, 2004

\begin{tabular}{llcccc}
\hline \multirow{2}{*}{ Location } & Farmer & Raw/comb & Filtered & Processed & Total \\
\cline { 2 - 5 } Hills & Small & $100(36)$ & - & - & $100(36)$ \\
Terai & Small & $20.0(2)$ & $80.0(8)$ & - & $100(10)$ \\
& Medium & $72.7(8)$ & $27.3(3)$ & - & $100(11)$ \\
& Big & $9.1(1)$ & $18.2(2)$ & $62.5(5)$ & $100(8)$ \\
& Sub total & $37.9(11)$ & $44.8(13)$ & $17.2(5)$ & $100(29)$ \\
& Total & $72.3(47)$ & $20.0(13)$ & $7.7(5)$ & $100(65)$ \\
\hline
\end{tabular}

Figures in parentheses show the respondent numbers

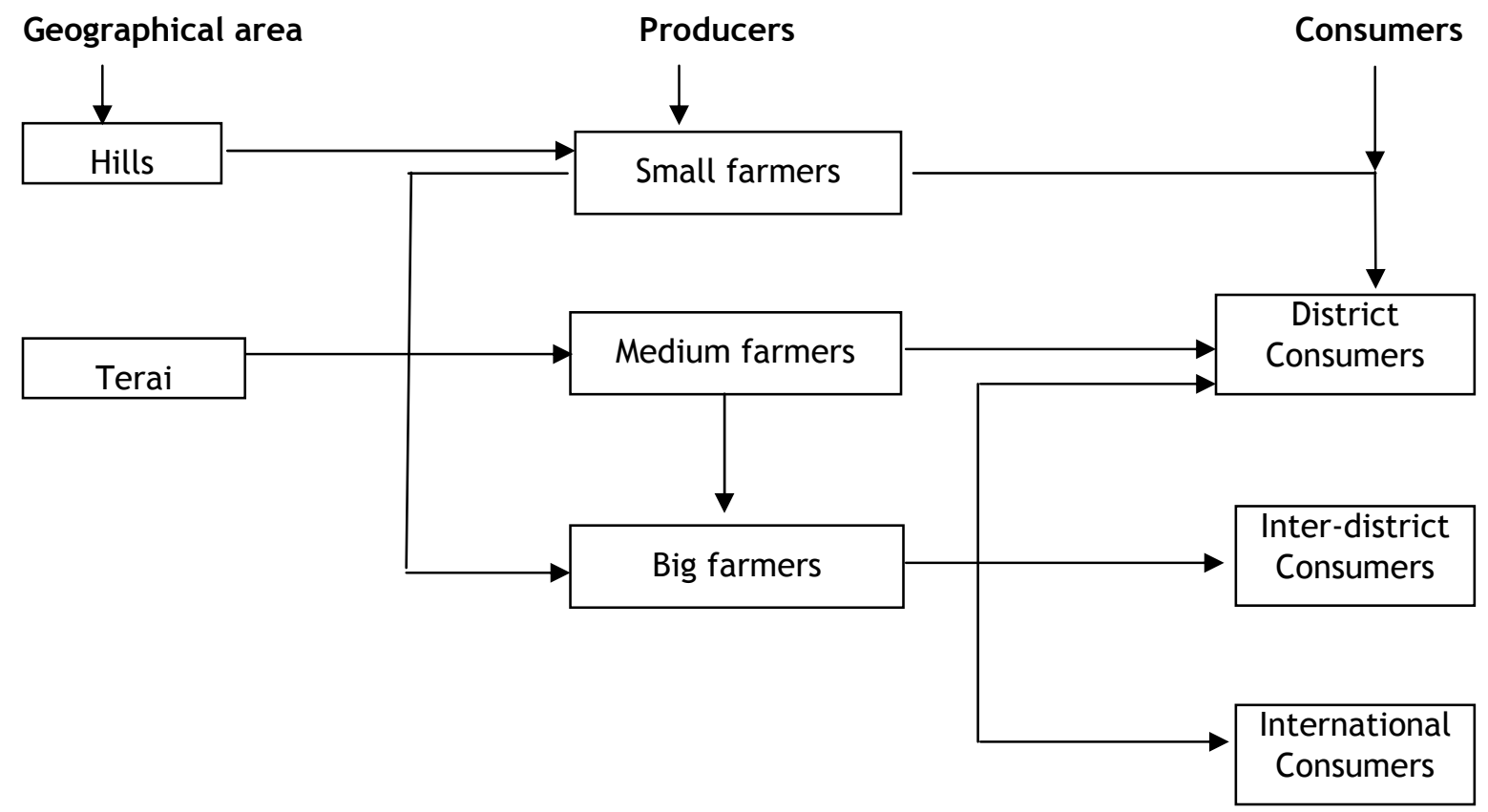

Figure 3. Marketing channel of honey in Chitwan, 2004. 
Income from honey marketing

The average annual gross income from beekeeping was Rs 3794.4 /household (Rs. 862.36 /colony/year) in hills and Rs 1,84,474.3 (Rs 3,689.49/colony/year) in Terai. The range of the annual income from $A$. cerana beekeeping in hills was Rs 1,200-7,200 per household per year, which was several folds less than that of $A$. mellifera beekeepers in Terai (Rs $12,000-11,50,000$ ) (Table 11). The average annual income of $A$. mellifera beekeeping in Bharatpur area was Rs 3,29,893 and was 475\% higher than that of West Chitwan and $90.2 \%$ higher than East Chitwan because of high number of the colonies kept by the beekeepers in Bharatpur.

Table 11. Honey production and household gross income in Chitwan, 2004

\begin{tabular}{|c|c|c|c|c|c|c|c|c|}
\hline \multirow{2}{*}{$\begin{array}{l}\text { Site/hive } \\
\text { type }\end{array}$} & \multicolumn{2}{|c|}{$\begin{array}{l}\text { Colony number } \\
\text { /hh }\end{array}$} & \multicolumn{2}{|c|}{$\begin{array}{l}\text { Productivity } \\
\text { (kg/hive/yr) }\end{array}$} & \multicolumn{2}{|c|}{$\begin{array}{l}\text { Honey price } \\
\text { (Rs) }\end{array}$} & \multicolumn{2}{|l|}{$\begin{array}{l}\text { Income } \\
\text { (Rs/year) }\end{array}$} \\
\hline & $\begin{array}{l}\text { Range/h } \\
\mathrm{h}\end{array}$ & Total & Range & Mean & Range & Mean & Range & Mean \\
\hline Hills & $4-12$ & $4.40(36)$ & $2-15$ & 8.1 & $100-150$ & 104.7 & $1200-7200$ & 3794.4 \\
\hline Improved & $2-12$ & $4.12(17)$ & $2-14$ & 8.6 & $100-150$ & & & \\
\hline Log hive & $1-6$ & $3.41(17)$ & $5-15$ & 7.7 & $100-150$ & & & \\
\hline Wall hive & $1-5$ & $2.80(15)$ & $3-15$ & 7.4 & $100-150$ & & & \\
\hline Terai & $10-250$ & $53.66(29)$ & $10-60$ & 28.7 & $100-150$ & 115.4 & $\begin{array}{l}12000- \\
115000\end{array}$ & 184474.3 \\
\hline West & $10-65$ & $23.13(8)$ & $10-35$ & 22.2 & $100-130$ & 109.0 & $\begin{array}{l}12000- \\
149500\end{array}$ & 57047.5 \\
\hline East & $10-95$ & $43.31(13)$ & $10-60$ & 34.8 & $100-120$ & 108.9 & $\begin{array}{l}13800- \\
627000\end{array}$ & 173401.9 \\
\hline Bharatpur & $10-250$ & $88.50(8)$ & $10-40$ & 25.1 & $115-150$ & 132.5 & $\begin{array}{l}15000- \\
1150000\end{array}$ & 329893.8 \\
\hline $\begin{array}{l}\text { District } \\
\text { total }\end{array}$ & $4-250$ & $25.01(65)$ & $2-60$ & 26.5 & $100-150$ & 114.3 & $\begin{array}{l}1200- \\
1150000\end{array}$ & 83996.8 \\
\hline
\end{tabular}

Figures in parentheses show the respondent numbers.

\section{Comparitive income from beekeeping with crop production}

The mean per capita gross agricultural income of the beekeepers in Chitwan was NRs 107211.10 per household per annnum. It was several folds higher in Terai than in hills (NRs 216492.40 vs NRs 19916.60). The per capita income was highest in Bharatpur (NRS 358264.30) followed by East Chitwan (NRs 208073.50) and West Chitwan (NRs 88357.60 /hh/year). The per capita income was higher by $261.83 \%$ from apiculture than crop cultivation (NRs 83996.88 vs NRs 23214.22 /hh/year). Out of the total income, $78.35 \%$ was from beekeeping and rest from crop production. Income from apiculture was highest in Bharatpur (92.08\%), followed by East Chitwan (83.33) and West Chitwan (64.56\%). However, in hills the per capita income from apiculture was lower (19.05\%) than crop production $(80.95 \%)$. It was because of the adoption of lower number of colonies by the beekeepers in hills and the productivity and production of honey were in smaller quantities. The beekeepers in hills are dependent to crop cultivation and other alternatives income generating activities although it was also found marginal (Nrs 16122.20/hh). It was highest in East Chitwan (Nrs 34691.63/hh) followed by West Chitwan 
(N31321.14/hh) and in Bharatpur (Nrs 28370.50/hh) (Table 12). Thus, the total income from agriculture in hills was several folds smaller than in Terai.

Table 12. Contribution of beekeeping in the household income in Chitwan, 2004

\begin{tabular}{lcccc}
\hline \multirow{2}{*}{ Location } & \multicolumn{3}{c}{ Income (NRs) } & $\begin{array}{c}\text { Apicultural } \\
\text { contribution (\%) }\end{array}$ \\
\cline { 2 - 4 } & Crop production & Honey production & Total & 19.05 \\
\hline Hills (36) & 16122.20 & 3794.40 & 19916.60 & 64.56 \\
West Chitwan & 31321.14 & 57047.5 & 88357.60 & 83.33 \\
$(13)$ & & & & 92.08 \\
East Chitwan (8) & 34691.63 & 173401.90 & 208093.50 & 85.21 \\
Bharatpur (8) & 28370.50 & 329893.80 & 358264.30 & 78.35 \\
Terai mean (29) & 32018.10 & 184474.30 & 216492.4 & \\
District mean (65) & 23214.20 & 83996.88 & 107211.10 & \\
\hline
\end{tabular}

Figures in parentheses show the respondent numbers

\section{Suggestions given from beekeepers}

A diagnostic laboratory for problem identification and provision of bee treatment, technical help and follow up support, breed selection, queen rearing and bee research program has been felt necessary in beekeeping for its commercialization in Chitwan. Beekeepers from the hills and Terai have suggested in many ways for the promotion of beekeeping in Chitwan. Modification of traditional log and wall hives, training on hive making, swarm capture and hiving, absconding control, better methods of honey harvesting and wax processing trainings are suggested by the $A$. cerana keepers. They also suggested for the development of low cost honey extractor. A. cerana race selection for better productivity and domestication has been felt necessary. However, the commercial A. mellifera keepers in Terai suggested for the advance level crop pollination and problem solving training and demanded a secured honey market and declaration of beekeeping policy and guideline from GoN. They demanded a diagnostic laboratory and provision of bee treatment follow up support and technical help from the government side. They are aware on the conflict arbitration on bee migration between beekeepers and bee crop growers and demanded interaction between the crop growers and beekeepers. Traffic problem on bee migration should be solved and GoN should attempt to control bee poisoning through legislative way.

\section{DISCUSSION}

Beekeepers adopted $A$. mellifera in Terai in improved hives and $A$. cerana in improved (41.1\%), traditional log (31.2\%) and wall hives $(27.6 \%)$ in hills. Devkota (2003) stated that the Chepang and the hill caste communities were adapting $A$. cerana in traditional hives in hi1ls. DADO $(2004 ; 2005)$ stated that $A$. mellifera multiplied during nineties and distributed through both farmers to farmers $(59 \%)$ and from DADO to farmers $(41.0 \%)$ in nineties in Terai. The average colonies in the hills were 4.4 and in Terai 50.0 per household. Labor engaged to manage these colonies were 1.6 in hills and 2.9 in Terai, which is in agreemenet with Neupane (2002). He estimated 5,500 A. mellifera and 2,000 $A$. cerana bee colonies in Chitwan in the year 2002. Beekeeping in Chitwan was mainly for income generation from honey selling as pointed by Bee Keeping Section (2003). However, considerable number of respondents $(27.8 \%$ in hills and $86.0 \%$ in Terai) realized the role of honeybees in crop pollination. Reddy (1995) estimated that crop production increased by 30 to 3000 percent through bee pollination. Devkota (2000) also agreed on the result that 
pollination could significantly improve both yield and seed quality of bee pollinated crops. Similarly, many crops benefited from bee pollination (Free, 1993, Pokhrel, 2001).

The hill and Terai respondents had an average landholding of 0.70 ha (irrigated 0.12 ha) and 0.57 ha (irrigated $0.34 \mathrm{ha}$ ), respectively which is smaller than national average of $0.727 \mathrm{ha} / \mathrm{hh}$ (Agri-Business Promotion and Statistics Division, 2005). Mean annual income from crop cultivation in hills (Rs $16,122.20 / \mathrm{hh}$ ) was lower by $49.6 \%$ than in Terai (Rs $32,018.00 / \mathrm{hh}$ ) and food sufficiency was only for 6.6 months in hills and 8.3 months in Terai. The per capita GDP is lower in hills and higher in Terai than the national average of Rs 20821 (Agri-Business Promotion and Statistics Division, 2005).

The productivity of $A$. mellifera was $254.3 \%$ higher $(28.7 \mathrm{~kg}$ vs $8.1 \mathrm{~kg} /$ colony/yr) than $A$. cerana (improved hive $8.6 \mathrm{~kg}$, log hive $7.7 \mathrm{~kg}$ and wall hive $7.4 \mathrm{~kg} / \mathrm{yr}$ ). The results was similar to the previous study (Devkota, 2000). The beekeepers harvested honey 2-7 (mean 3.2) times from $A$. cerana during autumn and spring in the hills and 3-7 times (mean 4.8) from $A$. mellifera in Terai during winter and spring. Where, East Chitwan farmers had highest honey harvesting frequency (5.3 times/year) with the highest productivity (34.8 $\mathrm{kg} /$ colony/year) followed by Bharatpur (4.6 frequency with $25.1 \mathrm{~kg} /$ colony/year) and West Chitwan (4.2 frequency with $22.2 \mathrm{~kg} /$ colony/year), respectively. The production, productivity and harvesting frequencies were highly correlated with flora availability, management practices adopted and the colony number kept by the beekeepers.

Honey price (wholesale) was found decreasing annually by $4.7 \%$ in Terai and by $3.9 \%$ in hills, which ranged from Rs 100-150/kg in the year 2004. The mean honey price decreased from Rs. 125 to 111 per $\mathrm{kg}$ in the past five years before 2003 in Chitwan (DADO, 2004). It was $9.2 \%$ lower (Rs 104.7 vs $115.4 / \mathrm{kg}$ ) in hills than in Terai and was highest in Bharatpur (Rs 132.5 vs 108.9 and 109.9) than in East and West Chitwan. The reason was increased volume of honey production and limited domestic market availability with limitation on honey export due to unavailability of residue monitoring facility in the country (Pokhrel, 2001). The mean per capita income of the beekeepers from beekeeping in Chitwan was NRs 107211.10 which was several folds higher in Terai than in hills (NRs 216492.40 vs NRs 19916.60).

The per capita income of the beekeepers was higher by $261.83 \%$ from apiculture than crop cultivation (NRs 83996.88 vs NRs 23214.22 / hh/year) although, it was lower $(19.05 \%$ vs $80.95 \%$ ) in hills because of the lower number of colonies kept by the beekeepers and lower honey production and productivity. In such cases, beekeeping can play a major role in poverty reduction and food security enhancement in Terai of Nepal. However, it needs special apicultural package of practices for the promotion of beekeeping in hills.

\section{CONCLUSION AND RECOMMENDATION}

The study realized that the hills needed a special package of practices for crop production that supported promotion of $A$. cerana beekeeping, which include educational activities, technical supports and extension of low cost technology to increase the productivity of $A$. cerana colonies.. In the Terai, A. mellifera was found promosing in terms of honey production, harvesting frequency, per capita colony holding and annual income, where commercialization of beekeeping with $A$. mellifera can earn higher than crop production. Hence, the demand of honey in both the domestic and external market is growing and to meet the demand an advanced apicultural research and extension mechanism including crop pollination and beekeeping trainings, a secured market for honey and formulation and implementation of clear beekeeping policy and guidelines by the government are recommended. 


\section{REFERENCES}

Agri-Business Promotion and Statistics Division. /2005. Statistical Information on Nepalese Agriculture, 2004/2005.125pp.

Beekeeping Section. 2003. Annual Progress Report, 2002/2003. Bee Keeping Section, Godavari, Lalitpur, Nepal. 57 pp.

Beekeeping Section. 2004. Annual Progress Report, 2003/2004. Bee Keeping Section, Godavari, Lalitpur, Nepal. 52 pp.

Devkota, F.P. 2000. Comparative pollination behavior of Apis cerana F. and A. mellifera L. on brocauli and their impact on seed production. Master Thesis Tribhuvan University, Institute of Agriculture and Animal Science, Rampur, Chitwan, Nepal.

Devkota, K.H. 2003. Economic impact of apiculture in Nepal (a case study of Jutpani VDC), Chitwan. Master Thesis. Tribhuvan University, Faculty of Humanities and Social Science, Birendra Multiple Campus, Bharatpur, Chitwan, Nepal. 76 pp.

District Agriculture Development Office (DADO). 2004. An overview of beekeeping and honey production in Chitwan district, Nepal. DADO, Chitwan, Nepal. 27 p.

District Agriculture Development Office (DADO). 2005. Barsik Krishi Bikas Karyakram Tatha Tathyanka. 2004. DADO, Chitwan, Nepal. 124 pp.

Free, J.B. 1993. Insect pollination of crops (second edition). London: Academic Press Inc. Ltd.

Neupane, K.R. 2002. Byabasaik Mauri Palanma Chitwan Jilla Agrasthanma. Chitwan Mahotsov Smarika Chitwan. pp.31. (in Nepali).

Pokhrel, S. 2001. Impact of supplement diets on brood and honey production of Apis mellifera L. Master's Thesis. Tribhuvan University, Institute of Agriculture and Animal Science, Rampur, Chitwan, Nepal. 103 pp.

Reddy, C.C. 1995. Management practices and migratory beekeeping. In: P.G. Kevan (ed.), The Asiatic hive bee: Apiculture, biology and role in sustainable development in tropical and subtropical Asia. Enviroquest Ltd., Canada. pp 209-215. 